\title{
Measurement and Drivers of Financial Inclusion in Cote d'Ivoire: A Case Study of Oil Palm and Rubber Tree Producers in Sud-Comoé Region
}

\author{
Hugues Kouadio ${ }^{1} \&$ Lewis Landry Gakpa ${ }^{1}$ \\ ${ }^{1}$ Ecole Nationale Supérieure de Statistique et d'Economie Appliquée (ENSEA) Abidjan, Côte d'Ivoire \\ Correspondence: Lewis Landry Gakpa, Ecole Nationale Supérieure de Statistique et d'Economie Appliquée \\ (ENSEA) Abidjan, 08 BP 03 Abidjan 08, Côte d'Ivoire. Tel: 225-0862-6436. E-mail: gakpalewis@yahoo.fr
}

Received: July 24, 2020

Accepted: August 8, 2020

Online Published: September 5, 2020

doi:10.5539/ijef.v12n10p11

URL: https://doi.org/10.5539/ijef.v12n10p11

\begin{abstract}
This study uses data collected by ENSEA within the framework of the Agricultural Sector Support Project in Côte d'Ivoire (PSAC) carried out in 2015 to measure, firstly, the financial availability, use and quality of financial inclusion of farmers in the rural region of Sud-Comoé of Côte d'Ivoire and, secondly, to examine the factors that influence their choices in terms of financial inclusion. To this end, we construct indices for each of the three dimensions (access, use and quality) and a synthetic financial inclusion index. The results of the univariate analysis reveal that farmers in the zone are poorly financially included in terms of the "use" and "quality" dimensions, and that the overall financial inclusion situation of farmers in the Sud-Comoé is low (33\% of farmers are financially included). To achieve the second objective, we used a logit model. The empirical results indicate that farmers with no schooling and fewer qualifications are more likely to be financially excluded; that the high cost of banking services and the low income of farmers limit their financial inclusion and, finally, that the experience acquired by farmers on the farm and the savings products offered by financial institutions are the factors that stimulate the financial inclusion of farmers. In addition, the education variable partly explains why financial inclusion is more frequent among rubber tree farmers than among oil palm farmers. In view of these results, economic choices and decisions must be targeted according to these empirical findings to increase the level of financial inclusion of producers, the true pillars of the economy of Côte d'Ivoire.
\end{abstract}

Keywords: financial inclusion, producers, Côte d'Ivoire

\section{Introduction}

Financial inclusion, defined as the use of formal financial services, is seen as a fundamental determinant of economic development (Beck, Demirgüc-Kunt, \& Levine, 2007; Bruhn \& Love, 2014; Zins \& Weill, 2016). The underlying reason is that with greater financial inclusion, previously financially excluded people will have the opportunity to invest in education, save and start businesses, which could contribute to economic growth and poverty reduction. Also, it is beneficial to economic activity as it facilitates savings and allows the accumulation and diversification of assets (Ndung'u et al., 2016). In addition, financial inclusion can empower women (Swamy, 2014) and contribute to financial stability (Han \& Melecky, 2013). An inclusive financial system is therefore desirable, as it will provide opportunities for all, especially the poor, the majority of whom are in sub-Saharan African countries, to access and invest funds, develop capital and reduce risk. Thus, as can be seen from both theoretical and empirical literature, there is consensus that financial inclusion contributes to improving the living conditions of the poor and marginalized or vulnerable groups in society by enabling them to access finance (AfDB, 2013; Soumaré et al., 2016).

With regard to the benefits of financial inclusion, developing countries have developed strategies to increase people's access to financial services. In Côte d'Ivoire, for example, some of the measures undertaken to reduce the proportion of the adult population excluded from financial services have focused on integrating disadvantaged social strata into the economic fabric, through the establishment of adapted financial services that offer sustainable conditions for both providers and beneficiaries. Although these efforts have led to an uninterrupted evolution of financial inclusion since 2011 (Note 1) $)^{1}$, this country still shows low levels of financial inclusion compared to the rest of the world. For example, $46 \%$ of adults have an account in a financial 
institution compared to $72 \%$ worldwide. $12 \%$ of adults have formal savings compared to $24 \%$ globally. $6.7 \%$ of the population has a loan from a financial institution compared to $12 \%$ globally. The situation is even more alarming for rural populations (Note 2) ${ }^{2}$. Therefore, it becomes imperative to understand the factors that hinder or improve people's access to financial services in order to guide policy actions.

Several reasons are generally advanced in the literature to explain the financial exclusion of populations in developing countries. Dasgupta (2009) classifies them into four categories. The first one is geographical: no financial agency (bank, microfinance, ...) in a given area. The second is related to the difficulty for a financial institution to be operational in a given area. The third is related to the type of products offered by the institutions, which may not meet with the approval of the applicants. The fourth relates to the expenses associated with banking products, which can be high. The fifth relates to the strategy of companies that may voluntarily seek to exclude a certain type of customer. Finally, the sixth is self-exclusion: some populations refuse to approach banks because they believe that all requests from them will be rejected. These challenges that limit the financial inclusion of excluded population groups are further accentuated in rural areas (De Olloqui, Andrade, \& Herrera, 2015) due, firstly, to low population density compounded by low income levels that offer very low margins to compensate for the high operating costs of integrating excluded populations. Secondly, the limited financial capacities of rural people restrict their demand, while those of financial service providers limit effective supply in the absence of products adapted to the needs and conditions of small rural producers. This situation is also exacerbated by the vulnerability of the rural environment to risks of various kinds (Argumedo, 2017), low rates of formal ownership that reduce the range of assets eligible for collateral (Valenzuela \& Cruz, 2017) and limitations in terms of coverage and quality of available infrastructure (Reyes, 2017).

However, greater financial inclusion in rural areas would increase the resilience of rural producers to climatic hazards, which frequently affect their production process (Cruz et al., 2017). It could also help mitigate the negative impact of these adversities by making it unnecessary for producers to liquidate productive assets, thereby reducing their chances of falling into the poverty trap and enhancing their ability to recover economically on their own (Carter et al., 2007). In addition, financial inclusion could enhance the capacity of small rural producers to generate savings (Karlan et al., 2014, Efobi et al., 2014).

Therefore, for all these good reasons, in this study, we approach the issue of financial inclusion on a very specific segment of the population: farmers (Note 3$)^{3}$ who are the largest class of the active population in Côte d'Ivoire and unfortunately the one most severely affected by financial exclusion. To our knowledge, due to a lack of data, no study based on primary data has yet been conducted on this category of producers.

This study is therefore an attempt to measure the financial availability, use and quality of financial inclusion of farmers in the rural region of South Cote d'Ivoire. More specifically, the aim is first to take stock of the overall situation of financial inclusion through the construction of a synthetic financial inclusion index, and second, to analyse the determinants of the financial inclusion of farmers of two main cash crops in the Sud-Comoé region of Côte d'Ivoire with a view to making recommendations to policy makers for greater financial inclusion of farmers. The choice of this area is justified by the fact that it remains one of the most dynamic agricultural zones in the country.

The data used in this study were collected by ENSEA as part of the Agricultural Sector Support Project in Côte d'Ivoire (PSAC) (Note 4) ${ }^{4}$ carried out in 2015 in the $n$ the Sud-Comoé region.

The rest of the paper is structured as follows. The second section presents stylized facts about the financial situation in the study area. Section 3 describes the data and methodology used to conduct the study. The results of the estimates are analysed and discussed in section 4 . The study concludes with a conclusion highlighting the main findings and policy recommendations.

\section{Stylized Facts about the Financial System in Côte d'Ivoire's Sud-Comoé Region}

Sud-Comoé is a region in the south-east of Côte d'Ivoire, close to the Ghanaian border. It benefits from a subtropical climate marked by two rainy seasons (one small and one large) and two dry seasons (one less severe than the other). This climate is therefore conducive to agricultural activities. Farmers in the region, taking advantage of this comparative advantage, have specialized more particularly in the production of perennial crops, the main ones being oil palm and rubber. The importance of these crops in the economy of Côte d'Ivoire can be appreciated through the following figures: Côte d'Ivoire is Africa's largest producer of natural rubber and the world's largest exporter, with an estimated annual production of 581,000 tonnes in 2017. Also, the country remains the second largest oil palm producer in Africa and the ninth largest in the world, with an annual production of about 2.5 million bunches. Natural rubber is the second largest agricultural export, while oil palm contributes $1.5 \%$ to GDP. 
Financially, this region is particularly disadvantaged. Indeed, the number of access points (representations of formal financial institutions) is 10 per 100,000 inhabitants, far behind the national average of 18 points per 100,000 .

Graph 1 (in the annex) gives an overview of the number of financial institutions (access point) per 100,000 inhabitants per region in Côte d'Ivoire. Côte d'Ivoire as a whole has almost 18 access points per 100,000 inhabitants with about five ATMs per 100,000 inhabitants (Findex, 2014). The access points are made up of banking institutions, microfinance institutions and those of Mobile Money. Overall, Côte d'Ivoire has 24 commercial banks, 28 microfinance institutions and 3 Mobile Money institutions established on its territory in 2014 with a total of 4.048 branches (Note 5) ${ }^{5}$. Like many African countries, this national average hides a very wide disparity within regions. More than half of the total access points are located in the city of Abidjan alone (58.75\%), the country's economic capital. The Sud-Comoé region, the focus of our research work, is among the regions in which the coverage rate is below the national average. This region has about 10 access points per 100,000 inhabitants. It has only 63 access points, or $1.56 \%$ of the country's total access points. The region's financial system is dominated by $43 \%$ commercial banks, $30 \%$ mobile money and $27 \%$ microfinance institutions.

Table A-1 (in the Annex) summarizes the information for this region. It shows that the majority of access points are located in the three main cities of the region. Moreover, banking institutions are the most represented in this region. National banks such as the Banque Postale and the Caisse Nationale des Caisses d'Epargne (CNCE) together own 52\% of the region's bank branches. These two institutions are public bodies whose aim is to enable low-income agents to benefit from the same services as those offered by private banks. Microfinance and mobile money institutions are only present in the major cities of the region, as are other banking institutions.

\section{Data and Methodological Framework}

\subsection{Description of Study Data}

The data used in this study were collected by ENSEA within the framework of the Agricultural Sector Support Project in Côte d'Ivoire (PSAC) carried out in 2015 in the Sud-Comoé region. In this survey, the source population amounted to 2.077 producers, among whom 728 responded that they grow rubber trees and 1.349 oil palm. From this population, a representative sample of 373 farmers was drawn. This sample, composed of 190 oil palm and 183 rubber tree producers, was weighted to represent the source population.

Table 1 presents some of the financial characteristics of producers in the region.

Table 1. Financial characteristics of farmers ${ }^{\mathrm{a}}$

\begin{tabular}{|c|c|c|c|c|}
\hline & & Oil palm & Rubber tree & Total \\
\hline \multirow[t]{3}{*}{1.} & Percentage of farmers in the sample & 64.95 & 35.05 & 100 \\
\hline & Men & 84.14 & 93.85 & 87.55 \\
\hline & Women & 15.86 & 6.15 & 12.45 \\
\hline \multirow[t]{3}{*}{2.} & Average age of farmers & 53 & 48.3 & 50.2 \\
\hline & Men & 52 & 48.4 & 50 \\
\hline & Women & 57.5 & 46.8 & 54 \\
\hline \multirow[t]{3}{*}{3.} & Percentage with or without account & & & \\
\hline & With an account & 53.78 & 72.34 & 60.28 \\
\hline & Without an account & 46.22 & 27.66 & 39.72 \\
\hline \multirow[t]{7}{*}{4.} & Percentage of farmers with an account ${ }^{b}$ & & & \\
\hline & Bank & 40.33 & 59.59 & 47.6 \\
\hline & Micro-finance & 25.05 & 23.48 & 24.38 \\
\hline & Mobile-Money (MM) & 46.96 & 44.41 & 45.88 \\
\hline & Cooperative & 2.84 & 3.6 & 3.16 \\
\hline & Formal institutions ${ }^{c}$ & 97.74 & 97.56 & 97.66 \\
\hline & Formal institutions (without MM) & 63.70 & 75.34 & 68.60 \\
\hline \multirow[t]{7}{*}{5.} & Percentage of farmers who do not use $f$ & & & \\
\hline & Distance & 7.98 & 1.43 & 6.33 \\
\hline & High cost of services & 6.22 & 10.29 & 7.24 \\
\hline & Paperwork & 7.51 & 2.86 & 6.34 \\
\hline & Distrust & 4.5 & 6.93 & 5.11 \\
\hline & Low income & 86.69 & 87.59 & 86.92 \\
\hline & No need for formal financial services & 5.71 & 10.97 & 7.03 \\
\hline
\end{tabular}


6. Saving with financial institutions within the last 12 months

\begin{tabular}{lccc} 
Tontine & 0.45 & 0.35 & 0.42 \\
Cooperative & 0.76 & 2.12 & 1.24 \\
Banking and microfinance & 13.75 & 25.96 & 18.03 \\
Hoarding & 86.24 & 70.24 & 80.64 \\
Mobile money & 0.45 & 1.77 & 0.91 \\
Borrowing from financial institutions within the last 12 months & & & \\
Tontine & 0.00 & 0.35 & 0.12 \\
Cooperative & 2.88 & 2.61 & 2.78 \\
Banking and microfinance & 5.19 & 7.03 & 5.83 \\
No loans & 92.24 & 90.01 & 91.46 \\
\hline
\end{tabular}

Note. ${ }^{\text {a }}$. The statistics given correspond to the shares in the population of Oil palm and Rubber tree producers and in the total population.

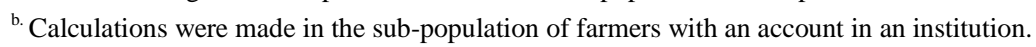

${ }^{c}$ Mobile Money has been added to the formal financial institutions.

d. Calculations were made in the sub-population of farmers who do not have an account in a formal institution.

Source: Authors' calculations.

After processing the data, it appears that $35 \%$ of the producers are rubber tree farmers and $65 \%$ are oil palm farmers. $60 \%$ of the farmers have an account, $48 \%$ of which is held in a banking institution and $24 \%$ in a micro-finance institution. Many farmers also have an account with "Mobile Money" institutions (46\%). The data also reveal that $81 \%$ of the population prefer to keep their assets on them (hoarding) and $82 \%$ do not save either in banks or microfinance institutions. Also, the number of farmers who have not taken out loans in the last twelve years is over $91 \%$. These results reveal that although farmers have an account, they are not frequent users of financial services.

To better assess the level of financial inclusion of the oil palm and rubber tree farmers, who are the subject of this study, we construct in the following sub-section an index for each of the three dimensions (access, use, quality $)^{6}$ and from a descriptive analysis, we present the share of the population excluded according to the three dimensions. The advantage of this approach is that it allows us to take into account all the variables likely to contribute to explaining the degree of financial inclusion of producers along each of the dimensions. Indeed, each dimension is a composite concept, as it is captured by a compilation of primary indicators. We continue the analysis to construct a Synthetic Index of Financial Inclusion (SIFI). With this last indicator, we examine through an empirical analysis the determinants of the financial inclusion of rubber tree and oil palm farmers of the Sud-Comoé region

\subsection{Construction of the Synthetic Index of Financial Inclusion (SIFI)}

The ISIF is a financial inclusion measure that is supposed to give an opinion on the overall financial inclusion situation of farmers. To construct it, we use a succession of methods. First, synthetic indicators of access, quality and use are computed, and then these indicators are aggregated using a standard Euclidean distance.

The synthetic sectoral indicators of financial inclusion are calculated according to the inertia method proposed by Asselin (2002). This approach uses factor analysis techniques, particularly multiple correspondence analysis (MCA) when qualitative variables are present. In principle, the method consists of performing a double MCA (a preliminary MCA (possibly) and a final MCA). The preliminary MCA takes into account all available and relevant variables characterising the financial inclusion dimension. It aims to select the primary indicators that will ultimately be used to construct the composite indicator. The first factorial axis of this MCA will highlight the financial inclusion of individuals. Thus, the primary indicators must imperatively respect the property of ordinal consistency along the first factorial axis (COPA). This property consists, for a variable, in seeing its ordinal structure of financial inclusion to be in line with the ordinal structure of the scores of its modalities. In other words, the purpose of these variables is to ensure that the degree of financial inclusion deteriorates (or improves) along the first factorial axis. For dichotomous variables, the COPA property simply means that the two modalities are opposed along the first factorial axis. The final MCA is done with the variables respecting the COPA property. It makes it possible to obtain weightings (weight/scores) for each of the modalities of the selected indicators. These weights are useful for calculating the value of the score for each dimension of financial inclusion for each individual. The formula proposed by Asselin (2002) for this calculation is as follows:

$$
I S(d)_{i}=\frac{\sum_{k=1}^{K} \sum_{j_{k}=1}^{J_{k}} W_{j_{k}}^{* 1, k} I_{j_{k}}^{i}}{K}
$$


Where $I S(d)_{i}$ is the synthetic index of the dimension $d$ for the producer $i ; K$ is the number of variables selected for the construction of the first factorial axis; $J_{k}$ is the number of modalities of the variable $k$ selected for the construction of the first factorial axis; $W_{j_{k}}$ is the normalized score of the modality $j_{k}$ on the first factorial axis; $I_{j_{k}}^{i}$ is a binary variable taking 1 if the producer $i$ has the modality $j_{k}$ and 0 otherwise.

Once the indicator has been calculated, there is now the problem of calculating the decision threshold. There is a non-arbitrary method for determining this threshold. It consists of constructing classes and then choosing among them the one that has the right financial inclusion properties in view of its characteristics. Next, the formula for the decision threshold in the case where the degree of financial inclusion increases with the scores is as follows:

$$
\text { Seuil }=\left(\min _{i}^{f}\right) * m_{i}^{f}+\left(\max C_{i}^{n f}\right) * m_{i}^{n f}
$$

With $\min C_{i}^{f}$ which represents the minimum of the value of the indicator in the class of individuals considered financially included; $m_{i}^{f}$ the class weight of individuals considered to be financially included; $\max C_{i}^{n f}$, the maximum of the indicator value in the other classes, and $m_{i}^{n f}$ the weight of the other classes. This methodology is used to construct the synthetic index for each dimension of financial inclusion and then the final financial inclusion indicator (SIFI) ${ }^{7}$.

\section{Results and Discussions}

\subsection{Descriptive Analysis of Indicators of Financial Inclusion of Oil Palm and Rubber Tree Farmers in Sud-ComoÉ Region}

The results in Table 2 show that the dimension of financial inclusion in which farmers are most vulnerable is that of quality. According to this dimension, only $0.53 \%$ of farmers are financially included. This low rate could be explained by the fact that the products or services designed by financial institutions do not take into account the aspirations of farmers and that there is no appropriate segmentation of clients to meet their needs in a specific way.

Table 2. Financial inclusion according to the different dimensions

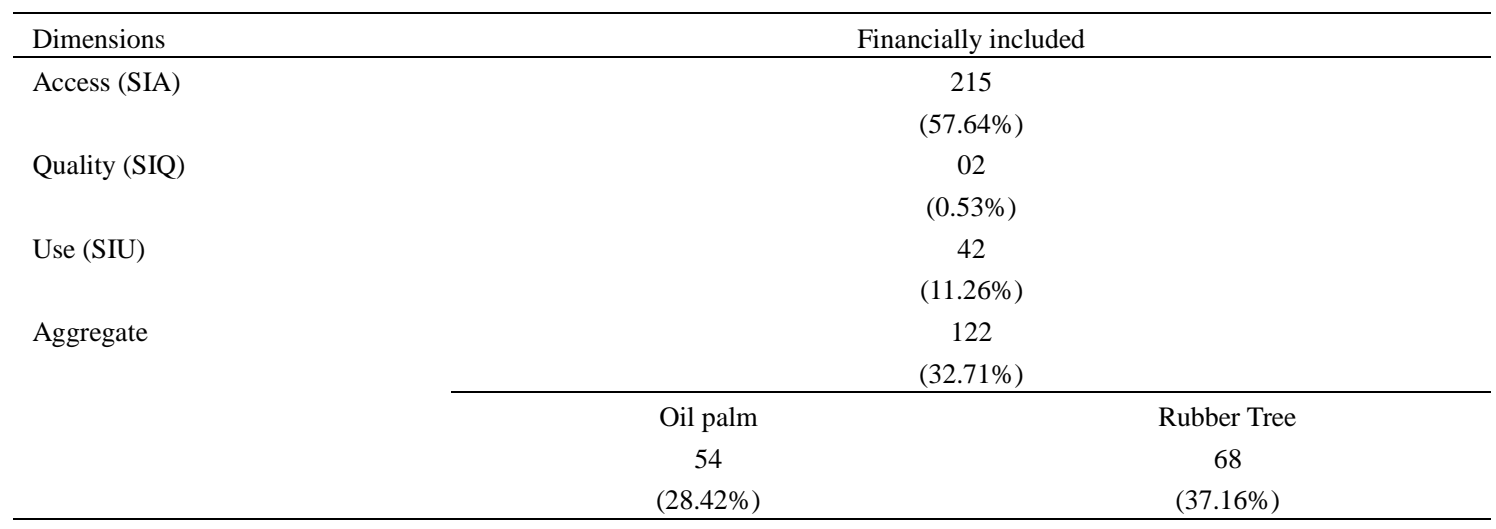

Source: Authors' calculations.

According to the use dimension (SIU) ${ }^{8}, 11 \%$ of the farmers are financially included. Even if the situation of financial inclusion according to this dimension is much better than according to the quality dimension, the proportion is still low. This index clearly shows us that although farmers have a bank account, they do not use it very often. This result is consistent with the data according to which $81 \%$ of individuals in the population prefer to hoard their assets and $82 \%$ do not save either at the bank or in microfinance institutions. The last access indicator reveals that 58\% are included under this indicator. Even if many formal institutions exist in the Sud-Comoé region and ensure physical proximity to most farmers, some efforts still need to be made to strengthen financial inclusion along this dimension. Indeed, apart from public banking institutions, most other financial institutions are only present in the major cities of the region. An effort to deploy other institutions in the region's other major cities will certainly improve people's access to financial services.

By and large, the overall situation of financial inclusion of farmers in the Sud-Comoé is low (33\% of farmers are financially included). It is clear from this description that efforts should be made, especially at the level of quality and utilization, to improve the financial inclusion of rubber tree and oil palm farmers in the Sud-Comoé region. 


\subsection{Econometric Analysis of the Determinants of Financial Inclusion}

We use econometric modelling to highlight the factors that influence the financial inclusion of farmers. Our dependent variable is constructed according to the ISIF. This index ranges from 0 to 1 , with 0 indicating the lowest degree of financial inclusion and 1 indicating the highest. Based on the assumption that above 0.5 , the individual can be considered as included and vice versa, we create a dichotomous variable (Included) that takes the value 0 when the ISIF for an individual is below 0.5 and 1 otherwise:

$$
Y_{i}=\left\{\begin{array}{rr}
1 \text { si ISIF } \geq 0.5 \\
0 \quad \text { otherwise }
\end{array}\right.
$$

The dichotomous nature of the dependent variable leads to binary choice models, (Bourbonnais, 2009): The Probit model or the Logit model. The results between the two types of model differ little (Amemiya, 1981). In this work, the Logit model is privileged.

Following the literature, the variables sex, age, level of education attained by individuals, the experience acquired by the individual on the farm, two measures to capture the obstacles to access to banking services (high cost of banking services, low income of farmers) ${ }^{9}$, two savings products (School_ Savings, Precaution_ Savings) used or not used by the farmers, two types of loans (Health _ Loans, School _ Loans) taken out or not taken out by the farmers and finally, we included the Oil palm variable to examine whether the type of products cultivated (oil palm or rubber tree) has an influence on the financial inclusion of the farmers. All these variables are therefore used to explain the financial inclusion of farmers.

To estimate this relationship, we use a logistic regression that can be written:

$$
P\left(Y_{i}=1\right)=P\left(\varepsilon_{i}<\alpha+X_{i}^{t} \beta\right)=F_{\varepsilon}\left(\alpha+X_{i}^{t} \beta\right)
$$

Where $Y_{i}$ indicates the variable of interest for individual $i$ as defined above. $F$ is the distribution function of the logistic law: $F(x)=\frac{1}{1+e^{-\frac{x-\mu}{s}}}$

With $E(\varepsilon)=\mu$ and $X_{i}^{t}$ the matrix of independent variables.

The results of the estimates are shown in Table 3 .

Table 3. Determinants of the financial inclusion of farmers

\begin{tabular}{llll}
\hline Variables & Included & dy/dx & odds ratio \\
\hline Sex & 0.618 & 0.056 & 1.855 \\
Oil Palm & $(0.734)$ & $(0.057)$ & $(1.376)$ \\
& $-0.773^{*}$ & $-0.085^{*}$ & $0.462^{*}$ \\
Primary School Certificate & $(0.438)$ & $(0.049)$ & $(0.193)$ \\
& $0.996^{* *}$ & $0.133^{*}$ & $2.708^{* *}$ \\
$1^{\text {st }}$ Cycle of Secondary School Certificate & $1.209^{* *}$ & $(0.070)$ & $(1.192)$ \\
& $(0.521)$ & $0.182^{*}$ & $3.350^{* *}$ \\
A-level Diploma & 1.225 & $(0.104)$ & $(1.810)$ \\
& $(0.832)$ & 0.198 & 3.404 \\
University $1^{\text {st }}$ and $2^{\text {nd }}$ years Level & $3.931 * * *$ & $(0.181)$ & $(3.148)$ \\
Bachelor_Master & $(0.929)$ & $0.754^{* * *}$ & $50.97 *$ \\
Experience & $2.288^{* *}$ & $(0.101)$ & $(103.7)$ \\
Age & $(0.966)$ & $0.451^{*}$ & $9.857^{* *}$ \\
High cost & $0.041^{*}$ & $(0.240)$ & $(11.05)$ \\
Income & $(0.022)$ & $0.004^{*}$ & $1.042^{*}$ \\
School_Savings & -0.000 & $(0.002)$ & $(0.0223)$ \\
& $(0.015)$ & -0.000 & 1.000 \\
\hline & $-1.948^{*}$ & $(0.002)$ & $(0.0158)$ \\
& $(1.004)$ & $-0.116^{* * *}$ & $0.143^{*}$ \\
& $-4.563^{* * *}$ & $(0.041)$ & $(0.149)$ \\
& $(0.795)$ & $-0.553^{* * *}$ & $0.0104 * * *$ \\
& 4.549 & $(0.053)$ & $(0.00840)$ \\
& $(4.904)$ & $0.811^{* *}$ & $(189.8)$ \\
\hline
\end{tabular}




\begin{tabular}{llll}
\hline Precaution _ Savings & $1.725^{* * *}$ & $0.299^{*}$ & $5.612^{* * *}$ \\
& $(0.607)$ & $(0.154)$ & $(3.363)$ \\
Health_L Loans & -0.438 & -0.041 & 0.645 \\
& $(0.836)$ & $(0.066)$ & $(0.550)$ \\
School_L Loans & 0.963 & 0,143 & 2.620 \\
& $(0.774)$ & $(0,151)$ & $(1.833)$ \\
Constant & -1.493 & & 0.225 \\
& $(0.931)$ & & $(0.240)$ \\
Observations & 370 & 370 & 370 \\
\hline Standard deviations are in brackets. ${ }^{* * *},{ }^{* *},{ }^{*}$ denote the significant threshold at $1 \%, 5 \%$ and $10 \%$ respectively.
\end{tabular}

The results show that the level of education, the experience acquired by the individual on the farm, the high cost of banking services, the low income of the farmers and the savings products offered by the banks are the factors that seem to best explain the financial inclusion of oil palm and rubber farmers in Sud-Comoé region.

With respect to educational attainment, the results confirm the findings of pioneering research that the probability of being financially included decreases with educational attainment (Shem et al., 2012). In other words, unschooled farmers and those with fewer qualifications are more likely to be financially excluded. Indeed, according to our results, when one moves from a farmer who has a primary, secondary or higher level of education, the probability that this farmer is financially excluded decreases by $0.13,0.181$ and 0.754 . As people become more educated, they better understand the value of financial services for the development of their business. Indeed, as infrastructure services, financial services permeate all economic activities, being very useful to the primary, secondary and tertiary sectors and to individuals. In the form of various banking, brokerage and insurance services, financial services facilitate domestic and international transactions, mobilize and channel domestic savings, and expand access to credit for small and medium-sized enterprises (SMEs) and households. They also facilitate trade. In addition, the experience gained by the individual on the plantation positively affects financial inclusion. This means that as the number of years spent as a farmer increases, one is more likely to be financially included.

The results also reveal that barriers to access to banking services significantly affect the level of financial inclusion of farmers. Indeed, the two reasons cited, namely the high cost of financial services and the low income of farmers, play a negative and statistically significant role in the financial inclusion of farmers. Also, according to the results, a farmer who is subject to income constraints is much less likely to be financially included than a farmer who is subject to the high cost of banking products.

Savings products (especially precaution savings) offered by banks to their customers seem to play a major role in their financial inclusion. This result implies that by developing specific products that take into account the real needs of farmers, financial institutions will contribute to reducing the financial exclusion of farmers in the zone.

Finally, it was investigated whether the type of product grown (oil palm or rubber tree) has an influence on the financial inclusion of the farmers. The results reveal that oil palm farmers are less financially included than rubber tree farmers. This result is compatible with those of Table 1. In fact, it is observed that $72 \%$ of rubber tree farmers have an account compared to $60 \%$ of oil palm farmers. In addition, $75 \%$ of rubber tree farmers have an account in a formal financial institution, compared to $64 \%$ of oil palm farmers. Rubber tree farmers save much more than oil palm farmers in banks and microfinance (26\% versus $14 \%$ ) and hoard relatively less. Another reason that may explain the fact that rubber tree farmers are better included financially than oil palm farmers is the level of education. Indeed, statistics (Table A-3 in the annex) reveal that the level of education of rubber tree farmers is much higher than that of oil palm farmers. However, the regression results clearly showed that there is a strong positive correlation between financial inclusion and education level. These elements could therefore help to understand why rubber tree farmers are better financially included than oil palm farmers.

\section{Conclusion}

In this study, we set ourselves the objectives, firstly, of taking stock of the financial inclusion situation of producers of two main cash crops in Côte d'Ivoire and, secondly, of highlighting the determinants of the financial inclusion of farmers.

To achieve the first objective, we constructed an index for each of the three dimensions (access, use, quality) of financial inclusion as well as a synthetic financial inclusion index. Thus, the results reveal that $58 \%, 11 \%$ and $0.53 \%$ of farmers are financially included, respectively according to access, use and quality dimensions. At the global level, the synthetic financial inclusion index shows that $33 \%$ of farmers $(37 \%$ of rubber tree farmers and 
$28 \%$ of oil palm farmers) are financially included. Overall, these results show the efforts that need to be made to improve the financial inclusion situation, especially for the use and quality dimensions.

Regarding the second objective, we have mobilized a logit model to highlight the factors stimulating financial inclusion. The results reveal that the level of education, the experience acquired by the individual on the farm, the high cost of banking services, the low income of the farmers and the savings products offered by the banks are the factors that seem to best explain the financial inclusion of oil palm and rubber tree farmers in Sud-Comoé region. In addition, the education variable partly explains why financial inclusion is more frequent among rubber tree farmers than among oil palm farmers.

In the light of these results, a number of policy implications can be formulated. First, it is important to note that education should not be neglected if policymakers want to increase the level of financial inclusion in Côte d'Ivoire. In the sense that the results reveal that the probability of being financially included decreases with the level of education. This result reaffirms the crucial role of human capital in a country's development. Moreover, strengthening the financial inclusion of producers will require, first, the introduction of products that are much more adapted to their lifestyle as farmers, second, policies to reduce the costs of financial products, and third, increasing the presence of financial institutions in the region.

\section{References}

African Development Bank. (2013). Financial Inclusion in Africa. Tunis: Thouraya Triki \& Issa Faye.

Amemiya, T. (1981). Qualitative Response Models: A Survey. Journal of Economic Literature, 19(4), 1483-1536.

Argumedo, P. (2017). Inclusión financiera de pequeños productores rurales: Estudio de caso en El Salvador. (LC/MEX/W.21), Project Documents, Mexico City, Economic Commission for Latin America and the Caribbean (ECLAC)/International Fund for Agricultural Development (IFAD), January.

Asselin, L. M. (2002). Pauvreté multidimensionnelle. Institut de Mathématique Gauss, Québec, Canada.

Beck, T., Demirgüc-Kunt, A., \& Levine, R. (2007). Finance, inequality and the poor: Cross-country evidence. Journal of Economic Growth, 12(1), 27-49. https://doi.org/10.1007/s10887-007-9010-6

Bourbonnais, R. (2009). Econométrie: Manuel et exercices corrigés (7th ed.). Dunod.

Bruhn, M., \& Love, I. (2014). The real impact of improved access to finance: Evidence from Mexico. Journal of Finance, 69(3), 1347-1376. https://doi.org/10.1111/jofi.12091

Carter, M. R., Little, P. D., Mogues, T., \& Negatu, W. (2007). Poverty Traps and Natural Disasters in Ethiopia and Honduras. World Development, 35(5), 835-856. https://doi.org/10.1016/j.worlddev.2006.09.010

Cruz, D., López, J., \& Valenzuela, C. (2017). The financial inclusion of small-scale rural producers in Honduras. Project Documents, Mexico City, Economic Commission for Latin America and the Caribbean (ECLAC)/ International Fund for Agricultural Development (IFAD), January. https://doi.org/10.18356/bf56dbc6-en

Dasgupta, R. (2009). Two approaches to financial inclusion. Economic and Political Weekly, 44(26/27), 41-44. Retrieved from https://www.jstor.org/stable/40279775

De Olloqui, F., Andrade, G., \& Herrera, D. (2015). Inclusión financiera en América Latina y el Caribe: Coyuntura actual y desafíos para los próximos años. IDB Discussion Paper, No. 385, Washington, D.C., Inter-American Development Bank (IDB). https://doi.org/10.18235/0000030

Demirgüç-Kunt, A., \& Klapper, L. (2012). Financial Inclusion in Africa. World Bank Policy Research Paper. https://doi.org/10.1596/1813-9450-6088

Demirgüç-Kunt, A., \& Klapper, L. (2013). Measuring Financial Inclusion: Explaining Variation in Use of Financial accross and within countries. Brookings Papers on Economic Activity, 279-321. https://doi.org/10.1353/eca.2013.0002

Efobi, U., Beecroft, I., \& Osabuohien, E. (2014). Access to and use of bank services in Nigeria: Microeconometric evidence. Review of Development Finance, 4(2) 104-114. https://doi.org/10.1016/j.rdf.2014.05.002

Han, R., \& Melecky, M. (2013). Financial Inclusion for Financial Stability. Access to Bank Deposits and the Growth of Deposits in the Global Financial Crisis. Policy Research Working Paper No. 6577, The World Bank, Washington, DC. https://doi.org/10.1596/1813-9450-6577

Karlan, D., Ratan, A. L., \& Zinman, J. (2014). Savings by and for the poor: A research review and agenda. 
Review of Income and Wealth, 60(1), 36-78. https://doi.org/10.1111/roiw.12101

Ndung'u, N., Morales, A., \& Ndirangu, L. (2016). Les dividendes de la révolution numérique. Finances \& Développement, Juin.

Reyes Luna, R. (2017). Inclusión financiera de pequeños productores rurales: Estudio de caso en la República Dominicana. (LC/MEX/W.24), Project Documents, Mexico City, Economic Commission for Latin America and the Caribbean (ECLAC)/ International Fund for Agricultural Development (IFAD), January.

Shem, O., Misati, R., \& Njoroge, L. (2012). Factors driving usage of financial services from different financial access strands in Kenya. Savings and Development, 36(1), 71-89. https://doi.org/10.2307/savideve.36.1.71

Soumaré, I., Tchana, T. F., \& Kengne, M. (2016). Analysis of the Determinants of Financial Inclusion in Central and West Africa. Transnational Corporations Review, 8(4), 231-249. https://doi.org/10.180/19186444.2016.1265763

Swamy, V. (2014). Financial inclusion, gender dimension and economic impact on poor households. World Development, 56, 1-15. https://doi.org/10.1016/j.worlddev.2013.10.019

Valenzuela, C., \& Cruz, D. (2017). Estudio de caso sobre estrategias para promover la inclusión financiera de pequeños productores rurales en Honduras. (LC/MEX/W.22), Project Documents, Mexico City, ECLAC subregional headquarters in Mexico.

Zins, A., \& Weill, L. (2016). The determinants of financial inclusion in Africa. Review of Development Finance, 6(1), 46-57. https://doi.org/10.1016/j.rdf.2016.05.001

\section{Notes}

Note 1. Financial inclusion increased from 34\% to $41 \%$ in 2017.

Note 2. For example, in rural Côte d'Ivoire only $9 \%$ of adults in rural areas have formal savings in a financial institution (Findex, 2017).

Note 3. Although the country is becoming less and less dependent on agriculture, which accounts for only $21.5 \%$ of GDP in 2017 compared to 32.5\% in 1990 (and even $47.9 \%$ in 1960), this sector continues to be the largest provider of jobs and foreign exchange for the country. The main cash crops are cocoa, coffee, cotton, oil palm, cashew nuts and rubber.

Note 4. The project was co-financed by the Cocoa Coffee Council and the World Bank Group.

Note 5. Mix-Market (2015)

Note 6. More details are provided in annex (Table A-2).

Note 7. Details on the construction of the different dimensions of financial inclusion are provided in annex (Table A-3).

Note 8 . The usage measures the actual use of financial products and services by crop owners. It also takes into account the regularity and frequency of use.

Note 9. The various reasons put forward to justify the non-use of banking services.

\section{Appendix}

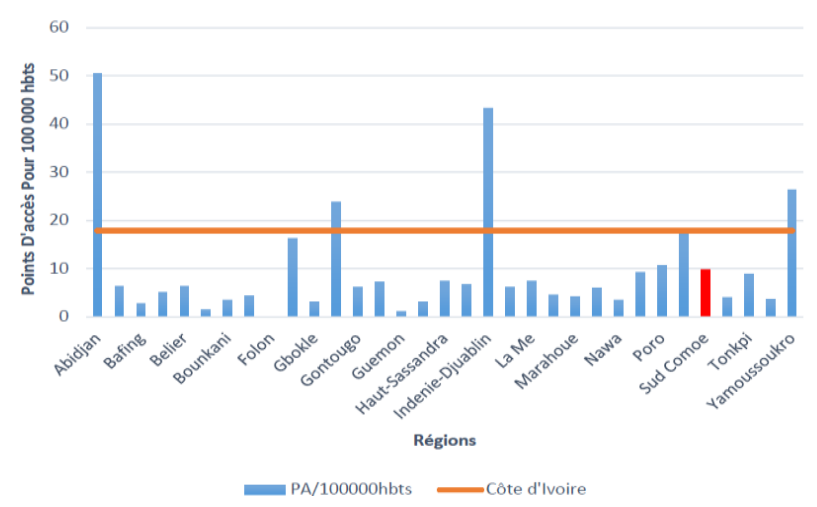

Figure 1. Coverage rate by region 
Table A1. Financial institutions in Sud-Comoé region

\begin{tabular}{llcc}
\hline & Institutions & Cities & Number of branches \\
\hline \multirow{4}{*}{ Banks } & BACI & Aboisso, Grand-Bassam & 2 \\
& BICICI & Aboisso & 1 \\
& BNI & Aboisso, Bonoua & 2 \\
& CNCE & Aboisso, Adiaké, Ayamé, Bonoua, Ehania, & 7 \\
& ECOBANK & Grand-Bassam, Krindjabo & 2 \\
& NSIA BANK & Aboisso, Grand-Bassam & 4 \\
& SGBCI & Aboisso, Bonoua, Grand-Bassam, Assinie & 2 \\
& POSTE & Aboisso, Grand-Bassam & 7 \\
\hline CEC & Aboisso, Adiaké, Grand-Bassam & 1 \\
Microfinances & Bromalah & Grand-Bassam & 7 \\
& COOPEC & Aboisso, Adiaké, Grand-Bassam & 1 \\
& FIDRA & Grand-Bassam & 5 \\
& RCMEC & Aboisso & 3 \\
\hline REMUCI & Celpaid & Aboisso, Adiaké, Grand-Bassam & 13 \\
\hline Total of Access points & Qash Services & Aboisso, Adiaké, Grand-Bassam & 6 \\
\hline
\end{tabular}

Table A2. Dimensions of financial inclusion

Dimensions $\quad$ Definition

Access Availability of formal financial services; Physical proximity; Lower cost

Use Actual use of financial services and products on a regular basis, with a fairly high frequency and in a sustainable manner over time

Quality Products are designed to take into account the needs of clients; adequate segmentation of financial products for all types of revenues.

Box: Description of the steps for the construction of the indicators

Step 1: Construction of the Synthetic Indicator of Access (SIA)

The MCA for this dimension was initially carried out on 13 qualitative variables corresponding to 32 active modalities. However, only two variables were retained for the final MCA. These are access to an account and the possibility of obtaining 60,000 FCFA in case of emergency. The results are that the first factorial axis provides $38.38 \%$ of the information. All the modalities of the two selected variables were used to calculate the synthetic indicator of access. To perform the Ascending Hierarchical Classification (AHC), we first had to choose the ideal number of axes to represent our data. The elbow criterion led us to choose the first two factorial axes which allow us to retain $71.72 \%$ of the total information. We then retain the AHC in two classes, as it is the most discriminating according to this last criterion. Class 1 is made up of producers who answered that they do not have an account. There are about $20 \%$ women in this class and $35 \%$ of individuals with no education at all. Class 2 , presumably that of financially included individuals according to the access dimension, is characterized by individuals who have at least one account in any financial institution, and for whom it would be perfectly possible to obtain money in case of emergency. This class contains male individuals (93\%) and producers with at least secondary education.

\section{$\underline{\text { Step 2: }}$ Construction of the Synthetic Indicator of Quality (SIQ)}

We use seven variables with a total of eighteen active modalities for MCA. At the end of the first investigation, we retain the following three variables: possession of a debit card, use of a mobile phone for transactions on a bank account and the variable online purchase or payment. Factor axis 1 provides us with $39.72 \%$ of the total information. All the modalities of the three selected variables are used in the calculation of the synthetic indicator of quality, SIQ. The classification according to this dimension of financial inclusion is done according to the first two factorial axes, accounting for $74.06 \%$ of the total information. This choice was always made using the elbow criterion. We have chosen to classify the data into 4 sub-groups. Class 1 is that of male farmers who did not declare having or not having a magnetic card (debit card). Class 2 contains male farmers who have a debit card but do not use the internet for transactions on their account or for purchases and payments. The class that clearly has the right characteristics for financial inclusion according to the quality dimension is the third one. This class contains $6.09 \%$ of the producer population. It includes male producers with a debit card (46\%) and contains all individuals who reported using their mobile phone for account transactions. Class 4 contains only producers who have used the internet in the last 12 months for purchases or payments. Three-quarters of them do not have a debit card. 
Step 3: Construction of the Synthetic Indicator of Use (SIU)

The MCA is based on a set of fourteen (14) variables for forty-nine (49) active modalities. After an eliminatory MCA, we retain four variables which are: - Deposits during the last 12 months (2 modalities); - Withdrawals during the last 12 months (2 modalities); - Number of withdrawals in one month ( 3 modalities); and - Savings during the last 12 months? (2 modalities). The first axis contains 54.49\% of the total information. For the classification, the elbow criterion suggested that we consider the first three (3) factors which allow us to retain $91.72 \%$ of the total information. We therefore classify the data into 4 sub-groups. Class 1 is composed of more than half of the producers. It contains those who declared that they have not saved in the last 12 months. These are generally women born in 1956. Class 2 contains more than one in ten producers. Individuals in this class have saved, deposited and withdrawn money in the last 12 months. $85 \%$ of these producers make an average of only one withdrawal per month. Class 3 is the class that is likely to have the best financial inclusion properties. These are producers who are intensive users of financial services. They constitute less than $5 \%$ of the total population of producers. They make deposits and withdrawals about twice a month. Class 4 consists of more than $25 \%$ of producers. These producers are those who have not carried out any deposit and withdrawal operations in the last 12 months.

Step 4: Construction of the Synthetic Indicator of Financial Inclusion (SIFI)

The SIFI indicator is constructed with the aim of providing a single indicator of financial inclusion. For this purpose, we use the three synthetic one-dimensional indicators previously constructed: SIA for the access dimension, SIQ for the quality dimension and SIU for the use dimension. The methodology we use is inspired by the methodology used for the calculation of the financial inclusion indicator by CRISIL and the Central Bank of India. CRISIL Inclusix is a macro dimension indicator whose construction methodology is inspired by the UNDP HDI and which measures the degree of financial inclusion in different regions of India. It thus makes it possible to quantify the impact of the efforts made by the Indian government in terms of policies to improve the financial inclusion of Indian populations. Like CRISIL Inclusix, we proceed in two stages: standardization and aggregation.

\section{Standardisation}

In this step, all one-dimensional synthetic indicators are standardised according to the following formula:

$$
X_{i}^{\text {norm }}=\frac{X_{i}-X_{i}^{\min }}{X_{i}^{\max }-X_{i}^{\min }}
$$

$X_{i}^{\text {norm }}$ is the value of the standardised indicator; $X_{i}$ is the synthetic indicator to be standardized ; $X_{i}^{\text {min }}$ is the minimum of the values of the synthetic indicator in question; $\mathrm{X}_{\mathrm{i}}^{\max }$ is the maximum of the values of the synthetic indicator in question. The synthetic indicators are standardised to take values between 0 and 1 , with 0 indicating the lowest degree of financial inclusion and 1 indicating the highest. This step also has the advantage of extracting the dimensional and unit effect of the various one-dimensional synthetic indicators.

\section{Aggregation}

We aggregate the indicators according to the following formula:

$$
\mathrm{ISIF}=1-\frac{\sqrt{\left(1-\mathrm{ISA}^{\text {norm }}\right)^{2}+\left(\left(1-\mathrm{ISQ}^{\text {norm }}\right)^{2}+\left(1-\mathrm{ISU}^{\text {norm }}\right)^{2}\right.}}{\sqrt{3}}
$$

It is the standardized Euclidean distance from the status of an individual represented by a triplet (SIA, SIQ, SIU) to the point of origin $(0 ; 0 ; 0)$ materialising the extreme case of financial exclusion.

Table A3. Type of plantation and level of education

\begin{tabular}{lcc}
\hline Level of education & Rubber tree & Palm oil \\
\hline None & $35.25 \%$ & $62.11 \%$ \\
Primary & $30.33 \%$ & $24.74 \%$ \\
Secondary & $27.87 \%$ & $10.53 \%$ \\
Higher & $6.56 \%$ & $2.63 \%$ \\
\hline
\end{tabular}

Source: Authors.

\section{Copyrights}

Copyright for this article is retained by the author(s), with first publication rights granted to the journal.

This is an open-access article distributed under the terms and conditions of the Creative Commons Attribution license (http://creativecommons.org/licenses/by/4.0/). 